\title{
Research on the Construction of Liberal Arts Graduate Student Learning Situation-A Case Study of the Tourism Management Major in Guangdong Province
}

\author{
Jun $\mathrm{Hu}^{1,2} \& \mathrm{Mu} \mathrm{Zhang}^{2}$ \\ ${ }^{1}$ Management School, Jinan University, Guangzhou, Guangdong, China \\ ${ }^{2}$ Shenzhen Tourism College of Jinan University, Shenzhen, Guangdong, China \\ Correspondence: Mu Zhang, Shenzhen Tourism College of Jinan University, Shenzhen 518053, Guangdong, \\ China. E-mail: Zhangmu@163.com
}

Received: January 22, 2015

Accepted: February 25, 2015

Online Published: March 23, 2015

doi:10.5539/hes.v5n2p1

URL: http://dx.doi.org/10.5539/hes.v5n2p1

\begin{abstract}
Currently there is inconformity between quality of graduate education and social demand in our country. Graduate students' ability can't meet the demand of national innovation and changing the cultivation mode of graduate student is imminent. Enlightened by the open and independent "student-centered" postgraduate education in foreign universities, based on the teaching theory of constructivism, researches suggests that to construct the learning situation which fits the independent learn and scientific research for liberal arts graduate students can solve the innovativeness problem during culturing graduate students. Study through the factor analysis of the questionnaire data obtains the four factors that affect the learning situation of liberal arts graduate students: the experimental condition, the independent learning condition, the team learning and the teacher practical. Through the multiple regression analysis, and facing the Tourism Experimental Teaching Center of Jinan University to do the empirical analysis, the research results on the one hand confirms that the Tourism Experimental Teaching Center of Jinan University has built a suitable learning situation for graduate students major in Tourism Management, on the other hand provides a train of thought and strategy for the build of learning situation for liberal arts graduate students.
\end{abstract}

Keywords: learning situation, liberal arts, graduate students, university, education

\section{Introduction}

The university is the forefront for the country to train top creative talents with education high quality. While graduate student education is at the top of the education level and it is an important part of higher education. The main advantage of constructing innovative countries in universities of developed countries is its large numbers of graduate students with high quality and the two goals of training talents and knowledge innovation achieved by graduate student education. So from the perspective of training talents, graduate student education in our country should also become the main channel of training creative talents in our country. Currently through research I find that there are still many problems existing in graduate student education: single training mode, teaching-oriented and scientific research-ignored, theoretic-oriented and practice-ignored, independent discipline limiting the development of universities which are treated as scientific research bases, etc. These series of problems lead to the low education quality of graduate students. However, in the old traditional graduate student education mode, the ability of graduate students is difficult to get promoted and inspired. In addition, the research is emphasis on the stage of postgraduate, but compared to the undergraduate courses most of the master's degree courses only to increase the task difficulty and enlarge the knowledge depth that is unlikely to get somewhere on the innovation achievement. There is no research atmosphere on campus for students and the lack of software and hardware situation supporting, the research enthusiasm discounts greatly. The current mode of talent training hardly matches up with the social demand and innovation and ability of graduate students can't meet the requirements when they enter the society. Facing that pressing problem, the graduate cultivation needs to find a new way and methods to perform adjusts and changes. We shall change "teach-oriented" into "learning-oriented" and improve the quality of graduate student education. By building suitable learning situations to inspire the independent learning and scientific research ability of graduate students, and gradually form a research atmosphere of 
integrating both teachers and students. That is an important way to train and bring up creative talents.

The research takes graduate students majored in Tourism Management of universities in Guangdong Province for instance to study what kind of situation can make liberal arts graduate students actively involving in learning and scientific research. For graduate students majored in Tourism Management, experimental environment is the key link in the process of developing their innovative ability. Laboratory itself is not only a scene for graduate students to develop the academic research but also the fundamental environment for autonomous learning of graduate students. The theory course teaching time in the graduate student education is very short. Project practice and laboratory research with relatively greater flexibility can provide effective help for cultivating the communication skills of graduate students. Research target is based on tourism experimental teaching center, around the core of improve the scientific research capacity for liberal arts graduate students majored in Tourism Management, explores that under the laboratory environment supporting, building learning situation of liberal arts graduate students majored in Tourism Management refers to which hardware and software environment in laboratory, and these background factors whether have effect on improving the scientific research ability of graduate students. In the end, try to shape a kind of situation which is suitable for liberal arts graduate students to participate in researching, experimental and innovative learning.

\section{Literature Review}

The experience of graduate students and talents cultivating in foreign countries gives much enlightenment to us. Since the 1990s in the developed countries especially in American, universities constantly improve educational innovation that adhere to students-oriented and the combination of in-class and after-class, science and humanities as well as teaching and researching, gradually formed a unique training model for innovative talents. In October 1998, the American universities pioneered the concept of "student-oriented" and the concept was written in the declaration of the World Conference on Higher Education of the United Nations Educational, Scientific and Cultural Organization (Cai, 2000). In American universities, entrepreneurship has become an important element of the campus culture. According to surveys, $23.7 \%$ of American universities set courses about entrepreneurship in the graduate student education, $38.7 \%$ of universities set courses about entrepreneurship both in the undergraduate student education and graduate student education. American universities attach great importance to the unity of both science education and humanistic education. Harvard University's interdisciplinary courses combine humanistic education and science education and each "Harvard University course" is in charge of several professors from different subjects in joint, or in charge of a teacher who has extensive interest in various disciplines (Zhang, 2004). In addition, American universities not only encourage students to participate in the professors' research topic and encourage each division department and professors to design topics which are suitable for students to involve in the research. The practice of developed country, apparently at the present stage has constructive significance for graduate education in our country. For graduate and high-level talents training target at home and abroad, the thinking of comprehensively promoting graduate student innovation consciousness and innovation ability is interlinked. We must build the situation of teaching and learning to provide the most basic situation for the opening, experimental and innovative exploration of the graduate students.

Constructivism was originally a kind of philosophical thinking. Some scholars think that "Socrates and Plato are the earliest constructors who against to acquire knowledge by means of direct teaching" (Nolar, 1997). Jean Piaget (1972) in Switzerland founded the school that is about children's cognitive development is the origination of constructivism teaching theory. Based on that, L. Kohlberg (1981) made a further study in the nature, the development conditions, etc. of the cognitive structure; R. J. Sternberg, D. Katz etc. emphasized the key role of the individual initiative in the process of constructing cognitive structure and carefully explored how to play the initiative of individual during the cognitive process (Leslie \& Jerry, 1995); Vygotskii (1997) proposed "the Development Theory of Culture and History" and emphasized the learners' role in the social cultural and historical background during the cognitive process. Based on that, the Villeru School headed by L. S. Vygotskii deeply studied the important role of "activity" and "social interaction" in the person's senior psychological function development (Shi \& Chen, 2003). The main points of constructivist teaching theory contain: learners do not passively accept the stimulation of news; the learning process is a process that learners use existing knowledge and experience to actively select the external information according to their own needs, interests and hobbies; and knowledge is a continuum established by each learner through the learning process (Cui, 2012). Domestic scholars, such as He Man, etc. (2006), apply the constructivism into the field of graduate student learning organization build, and the research result has shown the importance of situation building. Scholars such as Yang (2010), Jiang (2013), He (2013), etc., based on the build of graduate student learning organization, performed researches on the build method, necessity, build path, the obstacle factors of build and 
countermeasures in the past 5 years and finally all the researches refer to the build of the learning atmosphere has very important role on the build of learning organization.

All these studies have made constructivism theory enrich and perfect further and create conditions for the application in the actual teaching process. While the core of constructivism theory can be summarized only by one sentence: take the student as the center, emphasize students' active exploration and discovery towards the knowledge as well as the active construction of acquired knowledge. As the learning conditions required by the constructivism gain the strong contemporary support from the latest achievements of information technology which makes constructivism be generally combined with teachers' teaching practice, it has become the guiding ideology of schools at home and abroad to deepen teaching reform.

\section{Empirical Research}

\subsection{Research Case Selection}

Shenzhen Tourism College of Jinan University established the Tourism Management Experiment Teaching Center in 2005. The center assumes responsibility for experimental teaching task, arranging the whole laboratory resources, planning and designs various experimental courses and projects closely related to the demand of the tourism industry. Tourism Experimental Teaching Center organically combines his construction of laboratory technology platform with the construction of disciplines (as showed in Figure 1) and brings out the best in each other as well as make has obtained a good effect.

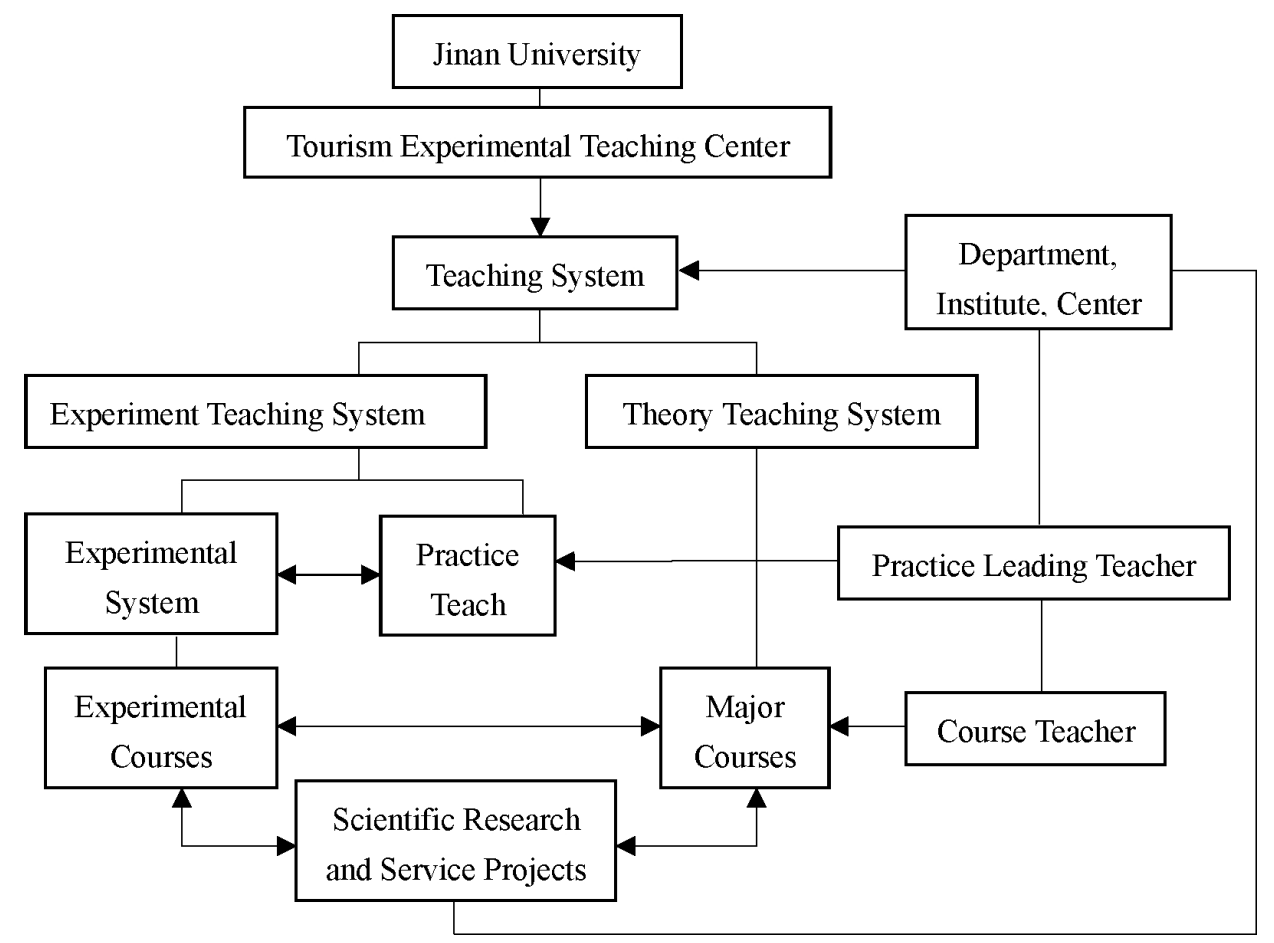

Figure 1. Operating mechanism of tourism experimental teaching center in Jinan University

Since the center was established, it has been awarded for numbers of prizes, including the prizes about students' scientific research achievements and the teachers' teaching achievements and it is fruitful in the education reform project at the provincial and ministerial-level and on the excellent courses at provincial level, etc. In 2001 and 2004, Shenzhen Institute of Tourism passed the reviews by Tourism Education Quality Certification System of World Tourism Organization by twice. The experiment center has launched more than 30 research projects in succession; since 2007 its students have awarded in challenge cup projects with a total number of 23, and it has awarded 29 undergraduate scientific technological innovation projects of Jinan University among which it wined 9 prizes of them. Under the guidance of teachers, the students used the experimental research platform of each professional laboratory to carry out all kinds of scientific research activities, and published nearly 30 valuable academic papers in the domestic and foreign journals and conferences. The center has trained a large number of professional tourism management talents for Hong Kong, Macao and Mainland China, especially Guangdong 
province which promotes tourism academic influence of Jinan University. Tourism Experimental Teaching Center of Jinan University, this comprehensive learning platform has built a kind of learning situation for graduate students majored in tourism management. That's why it is chosen as the research case.

\subsection{Research Design}

Though analyzing and systematizing related literature and related materials for the Tourism Experimental Teaching Center of Jinan University, this article hypothesized that the Tourism Experimental Teaching Center builds a suitable learning situation for graduate students majored in Tourism Management. In order to verify the validity of this situation, as well as to explore the influence factors of building effective situation, this research based on the constructivism theory, references satisfactory model and designs the questionnaire. For the particularity of the graduate students majored in Tourism Management in Guangdong Province, through interviews with the graduate students, the center staffs and teachers, preliminary formulates the index system of research questionnaire and carries on preliminary investigation among 35 students, as well as on the basis of the questionnaire data analysis revises the questionnaire.

\subsection{Research Object}

This research selects all the graduate students majored in Tourism Management from five universities in Guangdong province as the object of the questionnaire survey and collects effective questionnaire 116 totally with the recovery rate of $98 \%$.

\subsection{Variable Design}

The questionnaire mainly adopts Likert5 item-subscale and adopts a positive scoring method: 1 represents completely disagree; 2 represents almost disagree; 3 represents indifference; 4 represents almost agree; and 5 represents completely agree. The questionnaire divides into three parts. Variables are totally 30 items. The first part is the personal basic information investigation, including variables from 1 to 6 which respectively are: gender, educational background, degree, grade, the way of obtaining the postgraduate qualification, the way of graduate study; The second part is the information research on individual scientific situations, including variables from 7 to 10 which respectively are: average daily learning time, average daily time at the study site , number of participating scientific research item, number of published high quality papers; The third part is the attitude survey, specific variables distribution see the Table 1 .

Table 1. Measured variables of questionnaire on the learning situation of graduate student majored in Tourism Management in Guangdong Universities

\begin{tabular}{|c|c|c|c|c|c|c|}
\hline \multicolumn{7}{|c|}{ Total variables table } \\
\hline & Code & Measured Variables & Code & Measured Variables & Code & Measured Variables \\
\hline \multirow{7}{*}{$\begin{array}{l}\text { Measurement } \\
\text { Index of } \\
\text { Attitude }\end{array}$} & Q11 & Teaching courseware & Q18 & $\begin{array}{l}\text { Information } \\
\text { environment }\end{array}$ & Q25 & $\begin{array}{l}\text { Experimental data } \\
\text { processing }\end{array}$ \\
\hline & Q12 & Extracurricular books & Q19 & $\begin{array}{l}\text { Experimental } \\
\text { facilities }\end{array}$ & Q26 & Forum organization \\
\hline & Q13 & $\begin{array}{l}\text { Implementation of } \\
\text { teaching }\end{array}$ & Q20 & Laboratory & Q27 & Online discuss \\
\hline & Q14 & $\begin{array}{l}\text { Teachers' practical } \\
\text { experience }\end{array}$ & Q21 & Online courses & Q28 & Group learning \\
\hline & Q15 & $\begin{array}{ll}\text { Online learning } \\
\text { resources }\end{array}$ & Q22 & $\begin{array}{l}\text { Scientific research } \\
\text { project }\end{array}$ & Q29 & Group learning \\
\hline & Q16 & $\begin{array}{ll}\text { School network } \\
\text { resources }\end{array}$ & Q23 & $\begin{array}{l}\text { Experimental task } \\
\text { research }\end{array}$ & Q30 & $\begin{array}{l}\text { Independent } \\
\text { achievement }\end{array}$ \\
\hline & Q17 & Network condition & Q24 & $\begin{array}{l}\text { Appointed } \\
\text { experiment }\end{array}$ & & \\
\hline
\end{tabular}




\subsection{Reliability and Validity}

This questionnaire adopts Cronbach $\alpha$ coefficient to estimate the consistency reliability coefficient of the questionnaire. In calculating the coefficient of internal consistency in the revised Survey on the Learning Situation of Graduate Student Majored in Tourism Management in Guangdong Universities, found that the $\alpha$ reliability coefficient of the questionnaire is 0.891 which shows that the scale reliability is very good.

During processing the questionnaire data by KMO and Bartlett's spherical test, the result shows that the KMO value is 0.779 and significant $P$ value is 0.000 . KMO test coefficient $>0.5, P$ value $<0.05$, which suggests that the questionnaire has structural validity. And the value of KMO indicates the strong correlation among the different variables of the questionnaire. In addition to the anti-image matrix of data, the diagonal value $>0.5$, so the questionnaire is suitable for factor analysis.

\section{Data Analysis}

According to the survey of graduate students majored in Tourism Management in Guangdong Province. The author adopts SPSS19. 0 as the statistical software, and process the measuring result by data processing.

\subsection{Sample Analysis}

This research survey totally collects 116 valid questionnaires. Among the samples, men accounts for $23.3 \%$ women accounted for $76.7 \%$ and the proportion of men and women is about $1: 3$. The proportion is in conformity with the ratio of graduate students majored in Tourism management of universities in Guangdong province. Sample investigation involving all the graduate students from all grades of universities, among which grade one accounts for $38.8 \%$, grade two accounts for $37.1 \%$, grade three accounts for $24.1 \%$; and among which students whose graduate opportunities gained by passing the exam accounts for $52.6 \%$, recommended exemption graduate accounted for $47.4 \%$. The sample distribution is rather average.

\subsection{Factor Analysis}

After ensuring the questionnaire is suitable for factor analysis, process the data through principal component analysis and various rotation analysis and extract five factors and delete the variable whose factor load is less than 0.50. Analyzing the extracted four factors, get that: total explanation rate of cumulative variances reaches $63.523 \%$, explain rate exceeds $50 \%$ and that shows the information contained in the total variables scale is basically covered. In which $\mathrm{X}_{1}$ factors include Q19-Q25 variables and combined with the variables listed in table $1, X_{1}$ can be named as independent study conditions (ISC), by the same token, $X_{2}$ named as experimental condition (EC), $\mathrm{X}_{3}$ named as team learning (TL) and $\mathrm{X}_{4}$ named as teacher practicality (TP). The factor analysis results see the Table 2 .

Table 2. Analysis results of build factors of learning situation for liberal arts graduate students

\begin{tabular}{|c|c|c|c|c|c|c|c|c|c|c|c|}
\hline \multicolumn{3}{|c|}{$\begin{array}{c}\mathrm{X}_{1}: \text { ISC } \\
(\mathrm{a}=6.215, \mathrm{~b}=34.530 \%)\end{array}$} & \multicolumn{3}{|c|}{$\begin{array}{c}\mathrm{X}_{2}: \text { EC } \\
(\mathrm{a}=2.462, \mathrm{~b}=13.676 \%)\end{array}$} & \multicolumn{3}{|c|}{$\begin{array}{c}\mathrm{X}_{3}: \mathrm{TL} \\
(\mathrm{a}=1.473, \mathrm{~b}=8.186 \%)\end{array}$} & \multicolumn{3}{|c|}{$\begin{array}{c}\mathrm{X}_{4}: \mathrm{TP} \\
(\mathrm{a}=1.284, \mathrm{~b}=7.132 \%)\end{array}$} \\
\hline Item & $\begin{array}{c}\text { Load } \\
\text { Capacity }\end{array}$ & $\begin{array}{l}\text { Commu } \\
\text { nalities }\end{array}$ & Item & $\begin{array}{c}\text { Load } \\
\text { Capacity }\end{array}$ & $\begin{array}{l}\text { Commu } \\
\text { nalities }\end{array}$ & Item & $\begin{array}{c}\text { Load } \\
\text { Capacity }\end{array}$ & $\begin{array}{l}\text { Commu } \\
\text { nalities }\end{array}$ & Item & $\begin{array}{c}\text { Load } \\
\text { Capacity }\end{array}$ & $\begin{array}{l}\text { Commu } \\
\text { nalities }\end{array}$ \\
\hline Q12 & .521 & .497 & Q19 & .578 & .590 & Q26 & .675 & .557 & Q13 & .827 & .807 \\
\hline Q15 & .791 & .785 & Q20 & .772 & .683 & Q27 & .635 & .648 & Q14 & .719 & .624 \\
\hline Q16 & .569 & .499 & Q22 & .659 & .549 & Q28 & .814 & .761 & & & \\
\hline Q17 & .841 & .731 & Q23 & .568 & .579 & Q29 & .723 & .692 & & & \\
\hline Q18 & .866 & .786 & Q24 & .634 & .759 & & & & & & \\
\hline Q30 & .596 & .508 & Q25 & .700 & .589 & & & & & & \\
\hline
\end{tabular}

Note. "a" expresses the eigenvalues of the said factors and "b" expresses the contribution rate of the said factors.

\subsection{Regression Analysis}

According to the factors analysis of the data and the extraction of principal component, by known that the build of learning situation for literal arts graduate students is effected by factors such as the experiment condition, 
independent study condition, team learning, teachers' practice, etc., for establishing the causal relationship between the build of learning situation for literal arts graduate students and various influence factors, this research adopts the method of multiple regression analysis to construct mathematical model. Due to the concept of building learning situation for liberal arts graduate students is difficult to quantify, the research treats the four following aspects as the dependent variable to explain the build of learning situation for liberal arts graduate students: the average daily study time of the graduate student, the average daily study time at the study site, the number of participating scientific research item, and the number of published high quality papers. We set the average daily learning time (ADT-L) as the dependent variable $\mathrm{Y}_{1}$ and set the extracted the five influential factors as the independent variable $\mathrm{X}$, so the regression equation (1) can be represented as:

$\mathrm{Y}_{1}=\mathrm{a}_{0}+\mathrm{a}_{1} \mathrm{X}_{1}+\mathrm{a}_{2} \mathrm{X}_{2}+\mathrm{a}_{3} \mathrm{X}_{3}+\mathrm{a}_{4} \mathrm{X}_{4}$

Similarly, assume the average daily time at the study site (ADT-S) as the dependent variable $\mathrm{Y}_{2}$, assume the number of participating scientific research item (N-PSR) as the dependent variable $\mathrm{Y}_{3}$, and assume the number of published high quality papers (N-PHP) as dependent variable $\mathrm{Y}_{4}$, so the regression equation (2-4) can be represented as:

$Y_{2}=b_{0}+b_{1} X_{1}+b_{2} X_{2}+b_{3} X_{3}+b_{4} X_{4}$
$Y_{3}=c_{0}+c_{1} X_{1}+c_{2} X_{2}+c_{3} X_{3}+c_{4} X_{4}$
$Y_{4}=d_{0}+d_{1} X_{1}+d_{2} X_{2}+d_{3} X_{3}+d_{4} X_{4}$

This research adopts ENTER method for regression analysis. Regression analysis results see Table 3.

Table 3. Regression parameter summary table

\begin{tabular}{|c|c|c|c|c|c|c|c|c|c|c|c|}
\hline \multicolumn{6}{|c|}{$\mathrm{Y}_{1}:$ ADT-L } & \multicolumn{6}{|c|}{$\mathrm{Y}_{2}: \mathrm{ADT}-\mathrm{S}$} \\
\hline & \multicolumn{2}{|c|}{$\begin{array}{l}\text { Unstandardized } \\
\text { coefficients }\end{array}$} & \multirow{2}{*}{$\begin{array}{l}\text { Standardized } \\
\text { coefficients } \\
\text { Trial version }\end{array}$} & \multirow{2}{*}{$\mathrm{t}$} & \multirow{2}{*}{ Sig. } & & \multicolumn{2}{|c|}{$\begin{array}{l}\text { Unstandardized } \\
\text { coefficients }\end{array}$} & \multirow[t]{2}{*}{$\begin{array}{l}\text { Standardized } \\
\text { coefficients }\end{array}$} & \multirow[t]{2}{*}{$\mathrm{t}$} & \multirow[t]{2}{*}{ Sig. } \\
\hline & B & $\begin{array}{l}\text { Standard } \\
\text { error }\end{array}$ & & & & & B & $\begin{array}{l}\text { Standard } \\
\text { error }\end{array}$ & & & \\
\hline (Constant) & 1.672 & .051 & & 32.751 & .000 & (Constant) & 1.491 & .053 & & 28.216 & .000 \\
\hline $\mathrm{X}_{1}$ & .188 & .051 & .298 & 3.660 & .000 & $\mathrm{X}_{1}$ & .156 & .053 & .244 & 2.937 & .004 \\
\hline$X_{2}$ & .256 & .051 & .406 & 4.984 & .000 & $\mathrm{X}_{2}$ & .241 & .053 & .378 & 4.547 & .000 \\
\hline $\mathrm{X}_{3}$ & -.051 & .051 & -.081 & -.992 & .323 & $\mathrm{X}_{3}$ & -.023 & .053 & -.036 & -.428 & .670 \\
\hline $\mathrm{X}_{4}$ & -.031 & .051 & -.050 & -.610 & .543 & $\mathrm{X}_{4}$ & -.113 & .053 & -.177 & -2.126 & .036 \\
\hline \multicolumn{6}{|c|}{ Note: $\mathrm{R}^{2}=0.263, \mathrm{Sig}=0.000$} & \multicolumn{6}{|c|}{ Note: $R^{2}=0.234, \mathrm{Sig}=0.000$} \\
\hline \multicolumn{6}{|c|}{$\mathrm{Y}_{3}: \mathrm{N}-\mathrm{PSR}$} & \multicolumn{6}{|c|}{$\mathrm{Y}_{4}: \mathrm{N}-\mathrm{PHP}$} \\
\hline & \multirow{2}{*}{\multicolumn{2}{|c|}{$\begin{array}{l}\text { Unstandardized } \\
\text { coefficients }\end{array}$}} & \multirow{3}{*}{$\begin{array}{l}\text { Standardized } \\
\text { coefficients } \\
\text { Trial version }\end{array}$} & \multirow{3}{*}{$\mathrm{t}$} & \multirow{3}{*}{ Sig. } & & \multirow{2}{*}{\multicolumn{2}{|c|}{$\begin{array}{l}\text { Unstandardized } \\
\text { coefficients }\end{array}$}} & \multirow{2}{*}{$\begin{array}{l}\text { Standardized } \\
\text { coefficients }\end{array}$} & & \\
\hline & & & & & & & & & & $\mathrm{t}$ & Sig. \\
\hline & B & $\begin{array}{l}\text { Standard } \\
\text { error }\end{array}$ & & & & & B & $\begin{array}{l}\text { Standard } \\
\text { error }\end{array}$ & Trial version & & \\
\hline (Constant) & 2.302 & .091 & & 25.331 & .000 & (Constant) & 1.440 & .051 & & 28.100 & .000 \\
\hline $\mathrm{X}_{1}$ & .340 & .091 & .317 & 3.730 & .000 & $\mathrm{X}_{1}$ & .225 & .051 & .332 & 4.365 & .000 \\
\hline $\mathrm{X}_{2}$ & .210 & .091 & .195 & 2.298 & .023 & $\mathrm{X}_{2}$ & .306 & .051 & .453 & 5.949 & .000 \\
\hline $\mathrm{X}_{3}$ & .128 & .091 & .119 & 1.403 & .163 & $\mathrm{X}_{3}$ & .085 & .051 & .126 & 1.656 & .100 \\
\hline $\mathrm{X}_{4}$ & .226 & .091 & .210 & 2.471 & .015 & $\mathrm{X}_{4}$ & .109 & .051 & .161 & 2.119 & .036 \\
\hline \multicolumn{6}{|c|}{ Note: $\mathrm{R}^{2}=0.197, \mathrm{Sig}=0.000$} & \multicolumn{6}{|c|}{ Note: $\mathrm{R}^{2}=0.357, \mathrm{Sig}=0.000$} \\
\hline
\end{tabular}

According to the regressed data, the four standardized regression equations see the following equations which can explain learning situation building for liberal arts graduate students:

$\mathrm{Y}_{1}=0.298 \mathrm{X}_{1}+0.406 \mathrm{X}_{2}-0.081 \mathrm{X}_{3}-0.050 \mathrm{X}_{4}$ 
$\mathrm{Y}_{2}=0.244 \mathrm{X}_{1}+0.378 \mathrm{X}_{2}-0.036 \mathrm{X}_{3}-0.177 \mathrm{X}_{4}$

$\mathrm{Y}_{3}=0.371 \mathrm{X}_{1}+0.195 \mathrm{X}_{2}+0.119 \mathrm{X}_{3}+0.210 \mathrm{X}_{4}$

$\mathrm{Y}_{4}=0.332 \mathrm{X}_{1}+0.453 \mathrm{X}_{2}+0.126 \mathrm{X}_{3}+0.161 \mathrm{X}_{4}$

According to the determination coefficient (R2), the five independent variables can explain $26.3 \%$ of the total dependent variable Y1, explain $23.4 \%$ of the total dependent variable Y2, explain $19.7 \%$ of the total dependent Y3 and explain 35.7\% of the total dependent variable Y4. The regressed P value at four times are all 0.000 which all reach the significance level0.01, and that shows the significant correlation between independent variables and dependent variables and the linear relation of the regression equations is remarkable, therefore the fitting model is statistically significant at all times of investigation and the conclusions can generalize the whole.

\section{The Strategy of Building Learning Situation}

\subsection{The Condition of Independent Study has an Important Role and has the Greatest Effect Degree among the Influential Factors of Building the Learning Situation for Liberal Arts Graduate Students}

The condition of independent study is the important factor which affects the build of the learning situation for liberal arts graduate students. The ability, motivation and efficiency of independent study play a vital role during scientific research and ability cultivating of graduate students in school. According to the survey data analysis, improving the network condition of universities can provide better condition of independent study for liberal arts graduate students. Now on the network resources is far richer than the resources provided by entity schools and students can get more convenient independent study resources from the Internet. Shenzhen Institute of Tourism of Jinan University is covered by overall overlay network with good signal, and the signal is especially strong in the area of teaching and self-study which makes the graduate students can search information and download academic resources online very quickly during independent study. That greatly saves the time spent by graduate students to look for learning materials and improves the learning enthusiasm and learning efficiency of graduate students during independent study. Jinan University Library website contains many large databases which refer to both at home and abroad resources, it also contains various types of documents which can meet the needs of study and research for graduate students. In addition to the necessary physical library, Shenzhen Institute of Tourism of Jinan University also sets electronic reading room where equipped with dozens of computers to provide electronic documents and information for students; moreover, Shenzhen Tourism Experiment Center of Jinan University has its own official website and the website platform provides rich curriculum and teaching material for graduate students to view and download freely which further realizes the seamless joint between inside and outside the classroom by independent study. Therefore, strengthening the campus network coverage and signal strength, building the school network resources platform, enriching the online academic and research resources provided by school, etc. have important significance in building the appropriate learning situation for liberal arts graduate students in the information age.

\subsection{Experimental Condition has Significant Effects among the Factors of Building the Learning Situation for Liberal Arts Graduate Students}

Good experimental conditions and environment can let the liberal arts graduate students be more willing to devote themselves into independent study and scientific researches. Many liberal arts professional research needs experiments to explore and validation, such as the analysis of experimental data, exploration and construction of model, etc., and the most lacking conditions for liberal arts graduate students are good experimental conditions during scientific researches. Since the establishment of Shenzhen Tourism Experiment Center of Jinan University, it has gradually set up network technology lab, multimedia language laboratory, GIS and tourist information and technology laboratory, etc., and established all open simulation system for all major courses and multimedia case library for tourism discipline. Tourism Experimental Teaching Center currently contains the laboratory which integrated with food and beverage management, CRM, ERP, e-commerce and other management concept and management system, and intensively reflects the new achievement of the information development. In addition, courses set by Tourism Experimental Teaching Center refers to many campus research projects, and combined with the institutional arrangements of Trimester (namely between the two semesters each year, insert a short term during which the students go to the enterprises to work for two months under the guidance of both then professional teachers and the industry tutors) as well as the stereoscopic experimental teaching mode of the "trinity" on the three aspects of platform construction and management, experiment teaching and research, personnel training and social services, it provides students "open-ended" experimental learning environment. So, the improvement of the experimental conditions for the liberal arts graduate students in universities is primarily based on two aspects: on the one hand, open special laboratory for liberal arts graduate students which is 
equipped with experimental equipment to meet the liberal arts professional research and establish special experiment booking and management system to provide experiment environment emphasized hardware where liberal arts graduate students can perform specification research, depth research and actual operation research; On the other hand, require combining professional courses to open related experimental research for graduate students to promote literal arts graduate students actively turn from theory to voluntarily participate in scientific actual operation research and provide a free and open research environment based on interest for liberal arts graduate from the software aspect.

\subsection{Team Learning is the Important Influencing Factors of Building the Learning Situation for Liberal Arts Graduate Students}

Constructing team learning atmosphere is an important part during building the learning situation for liberal arts graduate students. Team learning is different from the individual learning because team learning and scientific research need communication and thinking collision. The team learning atmosphere building has a positive impact on the spirit of cooperation and team consciousness during liberal arts graduate students cultivating. Shenzhen Institute of Tourism of Jinan University is equipped with open learning environment at many places in the school: the small round tables and small long tables inside and outside the electronic reading room, outside the library, among the teaching building opening space, etc. are placed for students to conduct group study and discussion. Course assignments of Shenzhen Tourism Experiment Center of Jinan University are mostly assigned in the form of groups and the center sets a variety of researches in the form of teams. The center website platform is equipped with tourism management BBS and graduate student united group to promote online exchanges of scientific researches. All of these provide a good team learning environment for graduate students majored in Tourism Management. So facing the promotion of team learning, school authorities should provide open team learning space, provide more opportunities for team learning and scientific research, establish different academic BBSs of arts majors based on the school network which contain different courses and break the time and space limitations to provide an online academic exchange platform for liberal arts graduate student and to enhance the campus online academic environment.

\subsection{Teacher Practice Teaching Content is of Great Significance is for Building the Learning Situation for Liberal Arts Graduate Students}

Graduate student teachers are different from undergraduate teachers. They need the graduate students have more scientific research ability and accumulated scientific research experience than undergraduates during education, so graduate students teachers more pay attention to the field of research and theory practice. Teachers from Shenzhen Tourism Experiment Center of Jinan University involves in tourism, e-business, English, information, and other majors, and some of them have a multidisciplinary background, especially the teachers related with tourism and information have rich enterprise practice experience and experience of actual operating project. Based on this, facing the graduate student teaching the teacher from the center can better realize the combination of theory teaching and practice teaching, and can provide graduate students opportunities to participate in the actual operation through various channels. From another perspective, teachers with strong practical can develop the theory horizon of liberal arts graduate students and promote the students' interest in reality research questions, thus inspire the enthusiasm of their independent learning and research. So facing the cultivation of liberal arts graduate students the school should choose teachers with rich practical experience who also pays attention to the actual operation, and that can play a huge role in promoting the build of the learning situation for liberal arts graduate students.

\section{Conclusion}

Currently there is inconformity between graduate cultivation model and social demand in our country. The researched quality of cultivation and the teaching system are badly in need of reform, and the reform should be built on the improvement of the hardware and software environment. This research based on the constructivism teaching theory, in order to construct a suitable learning situation for literal arts graduate students, taking graduate students majored in Tourism Management from universities in Guangdong province for instance, facing Tourism Experiment Center of Jinan University to do the empirical analysis, explore the influencing factors of building learning situation for literal arts graduate students. Research performs the questionnaire survey on graduate students majored in Tourism Management from five universities in Guangdong province and processes the survey data by descriptive analysis, factor analysis and regression analysis. This research then extracts four effective factors through the factors analysis which respectively refers to independent learning condition, experimental condition, team learning and teacher practical. Through treating the average daily learning time, the average daily learning time on the study site, the number of scientific research item participating and the number 
of high quality papers publishing respectively as the dependent variables, process the data through multiple regression analysis and gets the four standardization regression equations. The analysis results confirms that the build of Tourism Experimental Teaching Center is beneficial to the learning situations of liberal arts graduate students, and the research takes the Tourism Experimental Teaching Center for instance puts forward the thinking and strategy for build the suitable learning situation for liberal arts graduate students. Research attempts to promote universities to create conditions which can promote liberal arts graduate students transforming from "passive" to "spontaneously-consciously-voluntary" by the above ideas and strategies. However, facing the current era of rapid development, it is no doubt that the software and hardware which accord with the development and requirement of the era will let graduate students grow faster. Taking graduate students majored in Tourism Management for instance, the rapid development of wisdom tourism has been an inevitable trend and it needs more software and hardware support. What's more, facing all the liberal arts majors, the cultivation of graduate students need experimental environment and learning situation, the new experimental environment should keep pace with the times, and all kinds of hardware and software in universities need to be updated regularly. In this, the study provides strategic advices on building and updating experimental conditions to universities through data analysis.

\section{Acknowledgement}

This article belongs to part of the research results of the "Research on the Situation Build for Scientific Research Ability Promotion of the Literal Arts Graduate Students (No. 2013JGXM-MS07)" of Graduate Student Education Innovation Projects in Guangdong Province in 2013.

\section{References}

Cai, K. Y. (2000). Based on Students' Comprehensive Development. Journal of Higher Education Research, 5, $11-15$.

Cui, Y. P. (2012). Sustainable Development Research on College students' English Independent Learning Ability under Multiple Learning Theory Horizon. Shanghai International Studies University.

He, M., Zeng, Z. H., \& Duan, Y. (2006). Constructivism Thought on Graduate Student Learning Organization. Science and Technology Management Research, 2, 134-136.

He, Y., \& Liang, Y. (2013). The Obstacle Factors of Graduate Students Learning Organization Construction and Countermeasures Analysis. Journal of Continuing Education Research, 6, 88-91.

Jean, P. (1972). The Principles of Genetic Epistemology. Routledge and K. Paul.

Jiang, D. Q., \& He, Y. (2013). The Necessity of Graduate Students Learning Organization Creation and the Exploration of Its Paths. Journal of Continuing Education Research, 4, 83-86.

Lawrence, K. (1981). The philosophy of Moral Development. Harper and Row.

Leslie, P. S., \& Jerry, G. (1995). Constructivism in Education. Lawrence Erlbaum Associates Inc.

Nolar. (1997). Constructivism in science and science education, a philosophical critique. Science and Education, $6(2-3), 58$.

Shi, W. S., \& Chen, J. L. (2003). Enlightenment of Activity Theory of Villeru School on the Research of Mental Health Education. Journal of East China Normal University (education sciences), 21(3), 83-96.

Vygotskii, L. S. (1997). Educational Psychology. St Lucie Press.

Yang, S., \& Xiong, H. (2010). Research on Graduate Student Learning Organization Construction Method. Journal of Education Management, 5, 33-36.

Zhang, X. P. (2004). Harvard Educational Reform. Shanghai Education, 10B, 52-54.

\section{Copyrights}

Copyright for this article is retained by the author(s), with first publication rights granted to the journal.

This is an open-access article distributed under the terms and conditions of the Creative Commons Attribution license (http://creativecommons.org/licenses/by/3.0/). 